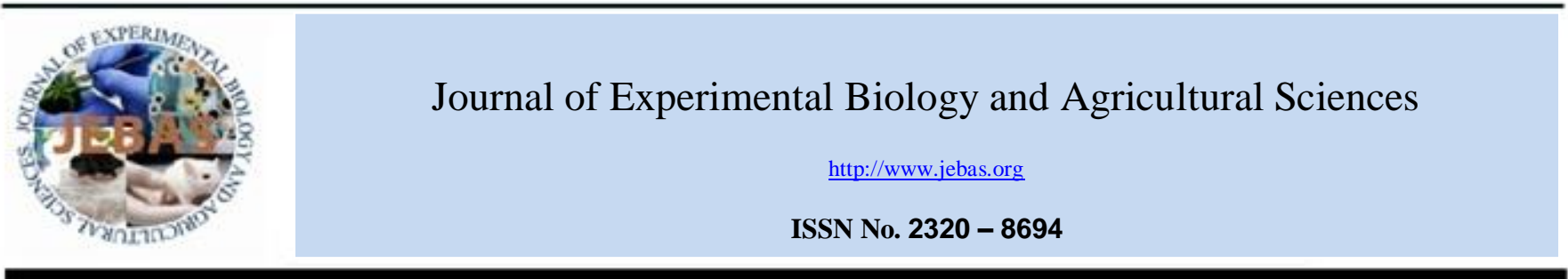

\title{
ISOLATION, PURIFICATION AND PARTIAL CHARACTERIZATION OF LOW MOLECULAR WEIGHT PEPTIDES FROM NONPRIMED AND HALOPRIMED SEEDLINGS of Vigna mungo L. AND Cajanus cajan L. AND THEIR IMPACT ON PHYSIOLOGICAL ASPECTS UNDER NaCl EXPOSURE
}

\author{
Sabarni Biswas ${ }^{1}$, Amitava Ghosh $^{2}$ Alivia Paul $^{1}$, Asok K. Biswas ${ }^{1 *}$ \\ ${ }^{1}$ Plant Physiology and Biochemistry Laboratory, Centre for Advanced Studies, Department of Botany, University of Calcutta, 35, Ballygunge Circular Road, Kolkata-700019. \\ ${ }^{2}$ Department of Botany, Ashutosh College, 92, Shyama Prasad Mukherjee Road, Kolkata-700026.
}

Received - November 28, 2018; Revision - January 02, 2019; Accepted - January 09, 2019

Available Online - February 5, 2019

DOI: http://dx.doi.org/10.18006/2019.7(1).12.24

\section{KEYWORDS \\ CD spectroscopy \\ Halopriming \\ HPLC analysis \\ Low molecular weight peptides}

MALDI-TOF

Salt stress

\begin{abstract}
Plants confront an array of environmental stresses by tightly regulating their signalling pathways involving low molecular weight peptide synthesis. In the conducted study, initially growth parameters and ion contents were measured from salt stressed and haloprimed seedlings of blackgram (Vigna mungo L.) and pigeonpea (Cajanus cajan L.). Seedlings raised from nonprimed and haloprimed seeds were grown in hydroponic solution supplemented with desired concentration of $\mathrm{NaCl}$ for 3 weeks under controlled physiological conditions. Attempts were made to isolate low molecular weight peptide(s) from non-stressed, $\mathrm{NaCl}$ stressed and haloprimed seedlings of blackgram and pigeonpea, to quantify their variations and detect their molecular weight using HPLC and MALDI-TOF analysis respectively. Free radical scavenging activities of these peptides were studied under $\mathrm{NaCl}$ exposure. Subsequent bioassays were performed to determine the effect of these peptides on their respective physiological parameters. Peptide abundance was maximum in control seedlings of both the cultivars, which under $\mathrm{NaCl}$ stress became scanty. $\mathrm{CD}$ spectroscopic analysis confirmed reduced secondary conformations and more unordered peptides under $\mathrm{NaCl}$ stress. Haloprimed seedlings recovered such adversities to variable extents, resulting in improved germination and growth of test seedlings.
\end{abstract}

* Corresponding author

E-mail: asokkbiswas16@gmail.com (Asok K. Biswas)

Peer review under responsibility of Journal of Experimental Biology and Agricultural Sciences.

Production and Hosting by Horizon Publisher India [HPI] (http://www.horizonpublisherindia.in/).

All rights reserved.
All the article published by Journal of Experimental Biology and Agricultural Sciences is licensed under a Creative Commons Attribution-NonCommercial 4.0 International License Based on a work at www.jebas.org.

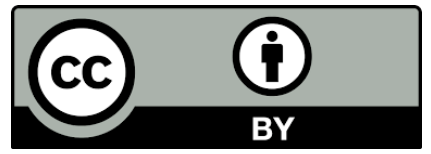




\section{Introduction}

Salt stress is an increasing environmental challenge that limits plant productivity in arid and semi-arid regions of the world (Hussain et al., 2009; Etesami \& Beattie, 2018). To confront under salinity, plants alter their physiological and biochemical mechanisms to withstand resulting stress (Parida \& Das, 2005). Biologically active low molecular weight (LMW) peptides play regulatory role in determining several physio-biochemical processes in plants under abiotically stressed conditions. Some of them help in amplification of signals (Lindsey et al., 2002), some act as regulators of signalling events and cell-to-cell communication in plants (Murphy et al., 2012; Albert, 2013; Czyzewicz et al., 2013; Matsubayashi, 2014; Oh et al., 2018), whereas some play essential role in nitrogen fixation (Mylona et al., 1995; Muñoz-García \& Ares, 2016). Small peptides play critical roles in cell proliferation, differentiation and mediate biotic and abiotic stress stimulation with metabolic intermediates (Mandal et al., 2008). Small signalling cysteine rich peptides have also been reported to play essential roles in stomatal patterning and density, symbiosis and a wide range of reproductive events viz., pollen tube formation, guidance and burst, activation of gametes and seed development (Hara et al., 2007; Sugano et al., 2010; Maróti et al., 2015; Bircheneder \& Dresselhaus, 2016). Few of these have been isolated and characterized in details. Systemin is probably the first sequenced plant peptide hormone (18 amino acid in length) which was isolated from Solanaceae species. Till now, peptides have been isolated and characterized in plants like bitter melon (Leung et al., 1987), broad bean (Zhang \& Lewis 1997), wheat (Ghosh et al., 2010) and mulberry (Jha et al., 2014). However, it has not been isolated from pulses like blackgram $(V$. mungo) and pigeon pea (C. cajan) exposed to high $\mathrm{NaCl}$ concentrations, to the best of our knowledge. Variations in levels of oxidative stress markers, activities of enzymatic and nonenzymatic antioxidants in $V$. mungo and $C$. cajan has been studied under salinity (Chatterjee et al., 2018) but, the variations in levels of the isolated LMW peptides from the same stands undone, so far as halopriming is involved. These pulses have been selected to work with since they are essential pulses often consumed as the cheapest source of protein. The prime purpose of the study lies not only in isolation and partial characterization of LMW peptides (having molecular weight between $0.3-5.0 \mathrm{kDa}$ ) induced by $\mathrm{NaCl}$ stress but also detection of antioxidative properties and conformational changes of these peptides in the chosen materials. The study also detects the efficacy of these LMW peptides isolated from haloprimed seedlings that favoured stress alleviation imparting better seedling performance. The worth of the study lies in the fact that since pulse production is extensively hampered in the saline regions, adopting cost effective, farmer friendly and environment friendly halopriming technique may help in improving pulse vigour and stand due to endogenous production of LMW peptides in abundance that could improve legume germination and growth of test cultivars under saline conditions.

\section{Materials and methods:}

Fresh and viable seeds of $V$. mungo cv. Sulata and $C$. cajan cv. rabi were sourced from Pulse and Oilseed Research Institute, Behrampore, West Bengal. Seeds surface sterilized with 5\% sodium hypochlorite solution for 15 minutes were divided into two batches. First batch was directly plated onto sterilized glass plates containing moistened blotting papers followed by their insertion into transparent plastic packets containing hydroponic solution (Widodo et al., 2009) which constituted the control set. For seeds to grow under salt stress, hydroponic solution ( $\mathrm{pH}$ 6.8) was supplemented with $150 \mathrm{mM} \mathrm{NaCl}$. This constituted the nonprimed sets. The second batch of seeds were allowed to soak in sublethal dose of $\mathrm{NaCl}(50 \mathrm{mM} \mathrm{NaCl})$ for 2 hours for the purpose of halopriming, prior to their germination in hydroponic solution containing $150 \mathrm{mM} \mathrm{NaCl}$. The set ups were exposed to 16 hours of photoperiod at $27-30{ }^{\circ} \mathrm{C}$ and $200 \mu \mathrm{molm}^{-2} \mathrm{~s}^{-1}$ photon irradiance (Biswas et al., 2018). Previous report (Chatterjee et al., 2018) revealed that at $150 \mathrm{mM} \mathrm{NaCl}$, significant effect of salt toxicity was recorded in the test cultivars. Therefore, this dose was chosen for conducting the present study. After 21days of growth, seedlings of each cultivar were harvested for peptide isolation. Extractions were carried out in cold room at $4^{\circ} \mathrm{C}$.

\subsection{Determination of morphological parameters}

After 21 days of growth, 10 seedlings were randomly harvested from control sets, salt stressed sets $(150 \mathrm{mM} \mathrm{NaCl})$ and haloprimed sets $(50 \mathrm{mM} \mathrm{NaCl}$ primed followed by their exposure to $150 \mathrm{mM} \mathrm{NaCl}$ ) of $V$. mungo and $C$. cajan seedlings for determination of salt induced damage in root and shoot length (Saha et al., 2010).

\subsection{Estimation of $\mathrm{Na}^{+}, \mathrm{K}^{+}$and $\mathrm{Cl}^{-}$contents}

$1 \mathrm{~g}$ of dried root and shoot samples from each set were utilized for $\mathrm{Na}^{+}$and $\mathrm{K}^{+}$ion estimation (Saha et al., 2012). Samples were placed inside muffle furnace at $450{ }^{\circ} \mathrm{C}$ for 24 hours in weighed porcelain crucibles to generate ash. The collected ashes were dissolved in $10 \mathrm{ml}$ of $2(\mathrm{~N}) \mathrm{HCl}$. The ash-acid extracts were filtered through Whatman filter paper (No. 42) into a $50 \mathrm{ml}$ volumetric flask. The volume was then made upto $50 \mathrm{ml}$ with 2 (N) $\mathrm{HCl}$. This filtrate was used for $\mathrm{Na}^{+}$and $\mathrm{K}^{+}$ion estimation using a Systronics Flame photometer Model No. 130.

Chloride $\left(\mathrm{Cl}^{-}\right)$contents were estimated from fresh shoot and root samples by titration (Sheen \& Kahler 1938). 1g root and shoot samples from each treatment was used for $\mathrm{Cl}^{-}$estimation. Samples were crushed in $10 \mathrm{ml}$ of Milli-Q water to which a pinch of 
charcoal was added and left undisturbed for 10 mins. Plant extracts were made charcoal free by repeated filtration and centrifugation. $\mathrm{Cl}^{-}$contents were estimated from filtrates by silver nitrate titration method.

Data obtained for the two cations $\left(\mathrm{Na}^{+}, \mathrm{K}^{+}\right)$were expressed in $\mathrm{mg} \mathrm{g}^{-1}$ dry weight and $\mathrm{Cl}^{-}$contents were expressed in $\mathrm{mg} \mathrm{g}^{-1}$ fresh weight.

\subsection{Extraction and isolation of LMW peptides}

For isolation and purification of LMW peptides, freshly harvested samples were pulverized in mortar and pestle using liquid nitrogen followed by its extraction in pre-chilled autoclaved distilled water. Extracts were centrifuged at $10,000 \mathrm{rpm}$ with protease inhibitor PMSF for half an hour to remove interfering materials. Collected supernatant was again centrifuged to purify it. Repeated ether washes of the extracts helped to remove fats, lipids and oils (Jha et al., 2016). The extracts were thereafter preserved at $-20^{\circ} \mathrm{C}$ for future experiments.

\subsection{Ion exchange Chromatography}

The peptide extracts were allowed to pass through cation and anion exchange resin columns (Dowex 50 and Dowex 1, Sigma Chemical Co., USA) (Azzoni et al., 2005). 3N ammonia and $1 \mathrm{~N}$ $\mathrm{HCl}$ was used for cation and anion exchange column respectively during peptide elution procedure. Extracted solution was made ammonia and $\mathrm{HCl}$ free with a Lyophilizer (Lyolab BII). Thus, the extracts were freeze dried to smaller volumes.

\subsection{Ultrafiltration}

Lyophilized peptide extracts obtained from control seedlings, $\mathrm{NaCl}$ treated seedlings and haloprimed seedlings were ultrafiltered through millipore stirred cell fitted with $5 \mathrm{kDa}$ (YM 5) and 0.3 (YC 03) ultrafilter membrane (Amicon made). Thus, the filtrate collected had peptides having molecular weight between 0.3-5.0kDa (Zehadi et al., 2015). During ultrafiltration, maximum pressure of $1.5 \mathrm{~kg} / \mathrm{cm}^{2}$ was maintained. The process was carried out thrice and the ultrafiltered samples were lyophilized and dissolved in $10 \mathrm{ml}$ distilled water (for each set) and cryopreserved.

\subsection{Purification and analysis of peptides through HPLC analysis}

High performance liquid chromatography (HPLC), Waters ${ }^{\mathrm{TM}}$ was performed with the extracted peptides. C18 column was used in $50 \%$ methanol (running solvent) fitted with 515 HPLC pump. A run time of 20 minutes and absorbance at $250 \mathrm{~nm}$ was recorded. Column length was of $3.9 \mathrm{~mm}$ X $150 \mathrm{~mm}$, injection volume $20 \mu \mathrm{l}$, flow rate of $0.5-1.0 \mathrm{ml} / \mathrm{min}$ (Jha et al., 2014) with pump pressure 4000psi was maintained. Peptide(s) obtained at retention time around $5 \mathrm{~min}$ was purified, concentrated and kept at $-20{ }^{\circ} \mathrm{C}$. The obtained peak was isolated and re-injected into column to check its repetitive occurrence. Thus, these peaks were concentrated and collected to study their effect on various physiological aspects.

\subsection{MALDI-TOF analysis}

Extracts purified through HPLC analysis were subjected to MALDI-TOF mass spectra measurements carried out on Ultraflextreme MALDI-TOF/TOF spectrometer, Bruker Corporation, Massachusetts, US, equipped with nitrogen laser wavelength. Dihydroxybenzoic acid (DHBA) was used as matrix. $30 \mathrm{mg} \mathrm{mL}$ DHBA prepared in water: acetonitrile (1:1). Individual peptide extracts were mixed thoroughly in $1 \mu 1$ of DHBA matrix solution and applied on sample plate in volume of $1 \mu 1$. Mixtures on sample plate were dried in an air stream followed by plate insertion into instrument for acquiring their respective spectra (Castañeda-Ovando et al., 2012).

\subsection{Circular Dichroism Spectroscopy}

Conformational changes in secondary structure of the isolated peptides was determined using $\mathrm{CD}$ spectropolarimeter (Model J715 , Jasco, Tokyo, Japan) at $25^{\circ} \mathrm{C}$ equipped with a temperature control unit using a $0.1 \mathrm{~cm}$ path length quartz cell (Senthilkumar et al., 2008). Spectral scans were undertaken within wavelength range of $280-195 \mathrm{~nm}$. The percentages of secondary structures were deconvoluted using BESTSEL program.

\subsection{Bioassays}

Isolated LMW peptides from 21days old V. mungo and C. cajan seedlings were used to test the following physiological traits:

\subsubsection{Germination test}

Surface sterilized seeds each of $V$. mungo and $C$. cajan were plated in petridishes to test their germination ability under salt exposure in presence of the peptides isolated respectively from their control seedlings, $150 \mathrm{mM} \mathrm{NaCl}$ treated seedlings and $150 \mathrm{mM} \mathrm{NaCl}$ treated haloprimed seedlings. Three replicates were made for each set of seeds. The set ups were kept in plant growth chamber at $21{ }^{\circ} \mathrm{C}, 68 \%$ humidity for one week under controlled condition of 16 hours of photoperiod followed by 8 hours of darkness.

\subsubsection{Stomatal bioassays}

Peels were made from abaxial surface of Colocasia esculentus L. leaves at $11 \mathrm{am}$. Initially peels were placed in water for two hours to prevent shock. Thereafter, peels were soaked in peptides isolated from control sets, $\mathrm{NaCl}$ treated sets and haloprimed sets 
of $V$. mungo and $C$. cajan for $60 \mathrm{mins}$ and mounted on glass slides to study the effect of LMW peptides on opening and closure of stomatal aperture.

\subsubsection{DPPH radical scavenging assay}

Free radical scavenging activities of the isolated peptides was assayed (Chrysargyris et al., 2016). Reaction mixture contained $1 \mathrm{ml}$ of $0.3 \mathrm{mM} \quad$ DPPH (1,1-diphenyl-2picrylhydrazyl) and $0.02 \mathrm{ml}$ of aqueous peptide extracts. The reaction mixtures were vortexed and incubated in dark for 30 minutes at $25^{\circ} \mathrm{C}$. Absorbance was measured at $517 \mathrm{~nm}$. Reaction mixture without test sample served as blank. The free radical scavenging activity was expressed as percentage of inhibition and calculated by the following equation:

$\%$ inhibition of DPPH activity $=\left[\left(\mathrm{A}_{\mathrm{s}}-\mathrm{A}_{\mathrm{b}}\right) / \mathrm{A}_{\mathrm{c}}\right] \mathrm{X} 100 \%$

where, $A_{b}$ is the absorbance of blank, $A_{s}$ is the absorbance of tested samples and $A_{c}$ is the absorbance of control samples.

\subsubsection{NO scavenging activity}

Nitric oxide (NO) scavenging assay was performed for the isolated LMW peptides (Jha et al., 2016). Nitric oxide generated from sodium nitroprusside was measured from Greiss reaction (Marcocci et al., 1994). 300 $\mu 1$ samples were mixed with $216 \mu$ l Greiss reagent (1\% sulphanilamide, 2\% $\mathrm{H}_{3} \mathrm{PO}_{4}$ and $0.1 \%$ NEDH [N-(1-napthyl) ethylenediamine hydrochloride] and $300 \mu \mathrm{l} 5 \mathrm{mM}$ sodium nitroprusside prepared in PBS (Phosphate buffer saline) solution. The reaction mixture was incubated for 60 minutes at $25^{\circ} \mathrm{C}$ in a water bath followed by the addition of $2 \mathrm{ml}$ water. The absorbance of the samples was taken at $546 \mathrm{~nm}$. Radical scavenging activity was calculated as percentage inhibition of NO radical by the following formula:

$\%$ inhibition of NO radical $=\left[\left(\mathrm{A}_{\mathrm{s}}-\mathrm{A}_{\mathrm{b}}\right) / \mathrm{A}_{\mathrm{c}}\right] \times 100 \%$

where, $A_{b}$ is the absorbance of blank, $A_{s}$ is the absorbance of tested samples and $A_{c}$ is the absorbance of control samples.

\subsection{Statistical analysis}

Experiments were carried out in completely randomized design (CRD) having three replicates. Data were mean values of three experimental sets and significant values were detected using one way ANOVA (Analysis of Variance) followed by Dunnett's Multiple Comparison Test which represented values that were significant at $\mathrm{p}<0.05$.

\section{Results}

\subsection{Effect of $\mathrm{NaCl}$ on growth}

$\mathrm{NaCl}$ exposure resulted in retarded growth of $V$. mungo and $C$. cajan seedlings. Root and shoot lengths were decreased by $22 \%$ and $21 \%$ in V. mungo and by $46 \%$ and $40 \%$ in C. cajan seedlings respectively over their control plants. Halopriming of seeds prior to germination narrowed down the rate of inhibition by $18 \%$ and $36 \%$ in root of $V$. mungo and C. cajan respectively whereas in shoot the inhibition was reduced to $17 \%$ in $V$. mungo seedlings and by $34 \%$ in C. cajan, on an average, over nonprimed control (Figure 1).
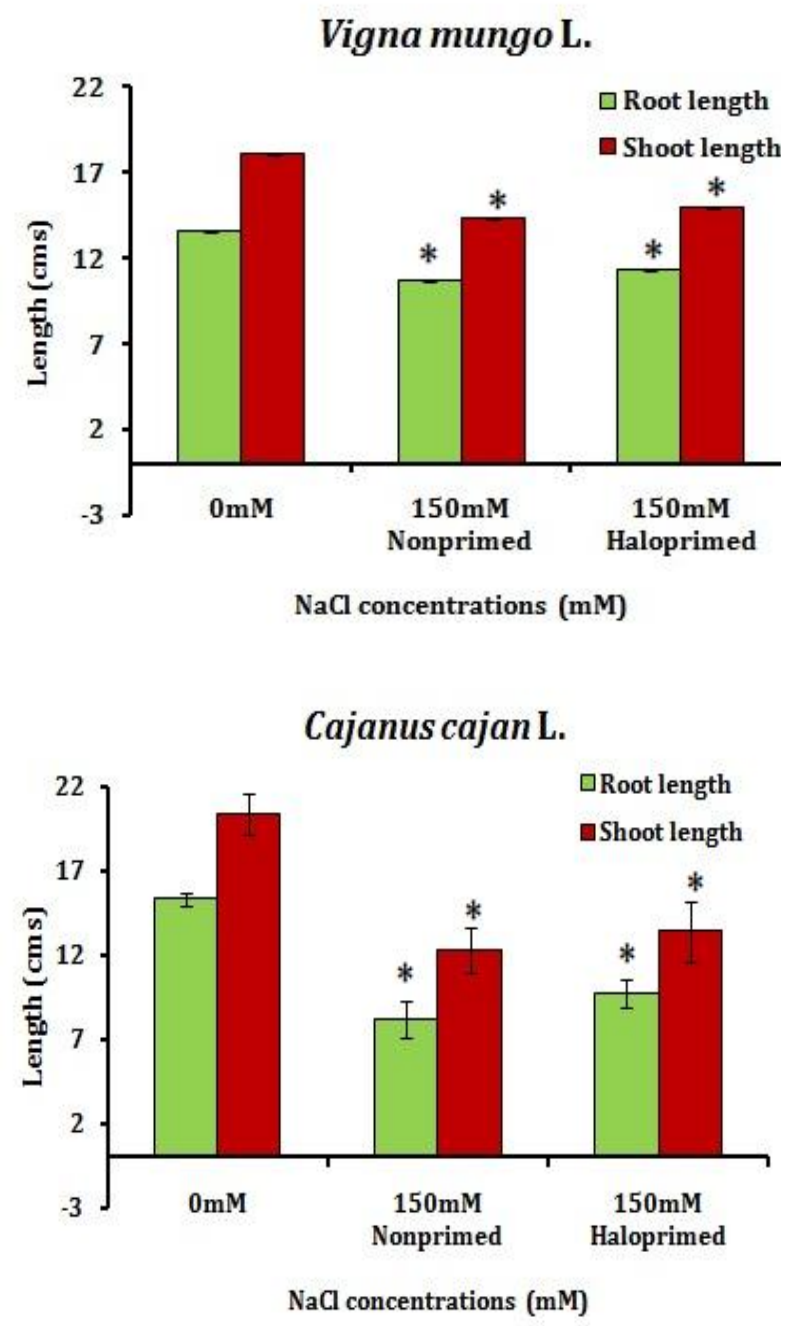

Figure 1: Effect of $\mathrm{NaCl}$ on root and shoot growth of 21 days old nonprimed and haloprimed seedlings of Vigna mungo and Cajanus cajan. Values are mean $\pm \mathrm{SE}$ with three replicates. * indicates statistically significant at $\mathrm{p} \leq 0.05$ compared to nonprimed control. 

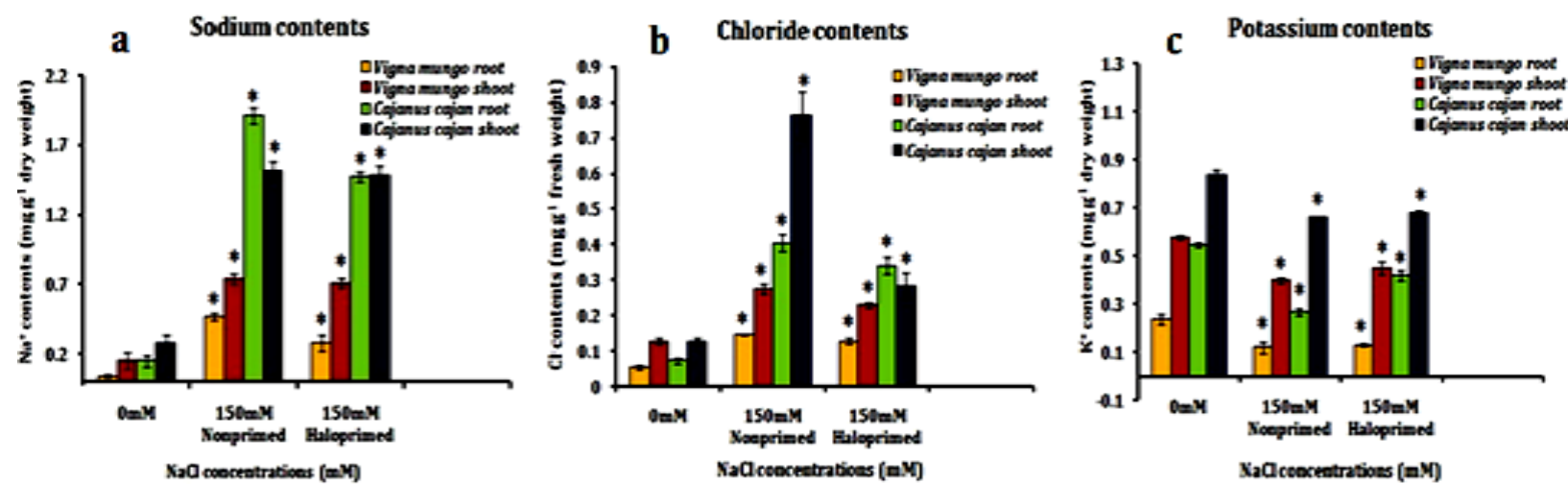

Figure 2 Effect of $\mathrm{NaCl}$ on $\mathbf{a} . \mathrm{Na}^{+}$contents, $\mathbf{b} . \mathrm{Cl}^{-}$contents and $\mathbf{c} . \mathrm{K}^{+}$contents of root and shoot of 21 days old nonprimed and haloprimed seedlings of Vigna mungo and Cajanus cajan. Values are mean \pm SE with three replicates. * indicates statistically significant at $\mathrm{p} \leq 0.05$ compared to nonprimed control.

\subsection{Effect of $\mathrm{NaCl}$ on $\mathrm{Na}^{+}, \mathrm{K}^{+}$and $\mathrm{Cl}^{-}$contents}

$\mathrm{Na}^{+}$and $\mathrm{Cl}^{-}$contents increased while $\mathrm{K}^{+}$contents decreased in root and shoot of both the legume cultivars on $\mathrm{NaCl}$ application (Figure 2a, b, c). The accumulation of $\mathrm{Na}^{+}$and $\mathrm{Cl}^{-}$was more in C. cajan than V. mungo. On an average, the uptake of $\mathrm{Na}^{+}$in nonprimed $V$. mungo and $C$. cajan increased on an average by 11 and 13-fold respectively in root whereas in shoot, the said increment was by 5 -fold in $V$. mungo and by 8 -fold in $C$. cajan over nonprimed control. Similar trend also was observed for chloride uptake. The chloride uptake, on an average, increased by $168 \%$ and $450 \%$ in root of $V$. mungo and $C$. cajan seedlings respectively whereas in shoot, the uptake increased by $114 \%$ and $493 \%$ in $V$. mungo and $C$. cajan respectively over non-primed control. Potassium content was found to decrease in root by about $50 \%$ in $V$. mungo and in C. cajan by $51 \%$ in nonprimed seedlings over control. In shoot of non-primed seedlings, the said content decreased by $31 \%$ in $V$. mungo whereas the contents were scaled to $21 \%$ in C. cajan.

Halopriming of both the cultivars with $50 \mathrm{mM} \mathrm{NaCl}$, before their germination in different concentrations of $\mathrm{NaCl}$, altered concentrations of ions in the test cultivars variably. Haloprimed seedlings showed lower uptake of $\mathrm{Na}^{+}$and $\mathrm{Cl}^{-}$ions along with increased accumulation of $\mathrm{K}^{+}$ions. Sodium uptake in haloprimed $V$. mungo seedlings was found to decrease 7 fold in root and by 4 fold in shoot, on an average, whereas chloride uptake was lowered down on an average to $133 \%$ in root and $79 \%$ in shoot over nonprimed control. The decrease in potassium contents was lowered to $46 \%$ in root and the decrement was further diminished to $22 \%$ in shoot of haloprimed $V$. mungo seedlings, over non-primed control.

In haloprimed C.cajan seedlings, $\mathrm{Na}^{+}$uptake was lowered down, on an average, by 10 -fold in root and by 5 -fold in shoot over nonprimed control. $\mathrm{Cl}^{-}$also accumulated in the test seedlings by $363 \%$ in root and $121 \%$ in shoot on an average over non-primed control. The inhibition in potassium uptake in $\mathrm{NaCl}$ primed seedlings of $V$. mungo diminished to $24 \%$ in root and $19 \%$ in shoot over nonprimed control attributing better seedling performance.

\subsection{HPLC chromatogram}

The HPLC chromatogram of the peptide(s) isolated from 21 days old $V$. mungo and $C$. cajan seedlings unambiguously discriminated the variation in presence of different content of LMW peptides $(0.3-5 \mathrm{kDa})$ indicated by varying peak area and peak heights.

From the HPLC chromatograms of the peptides obtained from control seedlings, $150 \mathrm{mM}$ salt treated seedlings and haloprimed seedlings, it is evident that in control seedlings, there was maximum expression of peptide at retention time (RT) 5.14 mins in $V$. mungo which indicates its abundance during seedling growth especially when LMW peptide is concerned. This expression was followed by several other peptides upto $\mathrm{RT}=8.5 \mathrm{mins}$. But, in $\mathrm{NaCl}$ treated seedlings the authors speculated that though the peak at RT=5.18 retained, but its abundance was found to decrease by $82 \%$ over peptides isolated from control sets. Only two low abundance peaks till before 8.0 minutes were observed in $\mathrm{NaCl}$ treated seedlings. This indicated that under salt stress several peptides that usually take part in the growth process of the plant were degraded. In the haloprimed seedlings, the peaks that were found to get degraded in salt treated sets revived at RT's 7.2 and 8.5 respectively with the highest peak obtained at $\mathrm{RT}=5.222$. The peak at $\mathrm{RT}=5.222$ in haloprimed seedlings, provided an area which was about $4 \%$ greater than the area of the same peak obtained from $150 \mathrm{mM}$ salt treated seedlings and the inhibition in peptide content was reduced to $80 \%$ over control peptides (Figure 3a). 

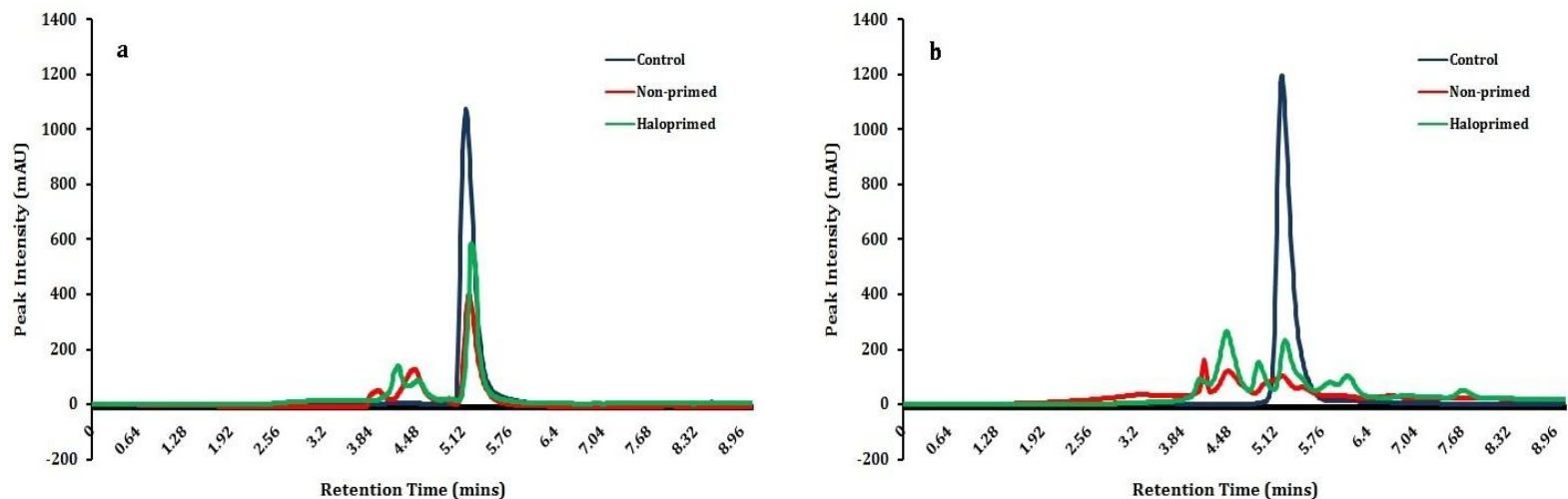

Figure 3 HPLC chromatogram indicating variation in the intensity and content of LMW peptides from control, non-primed salt stressed (150mM) and haloprimed salt stressed (150mM) sets in a. Vigna mungo b. Cajanus cajan.
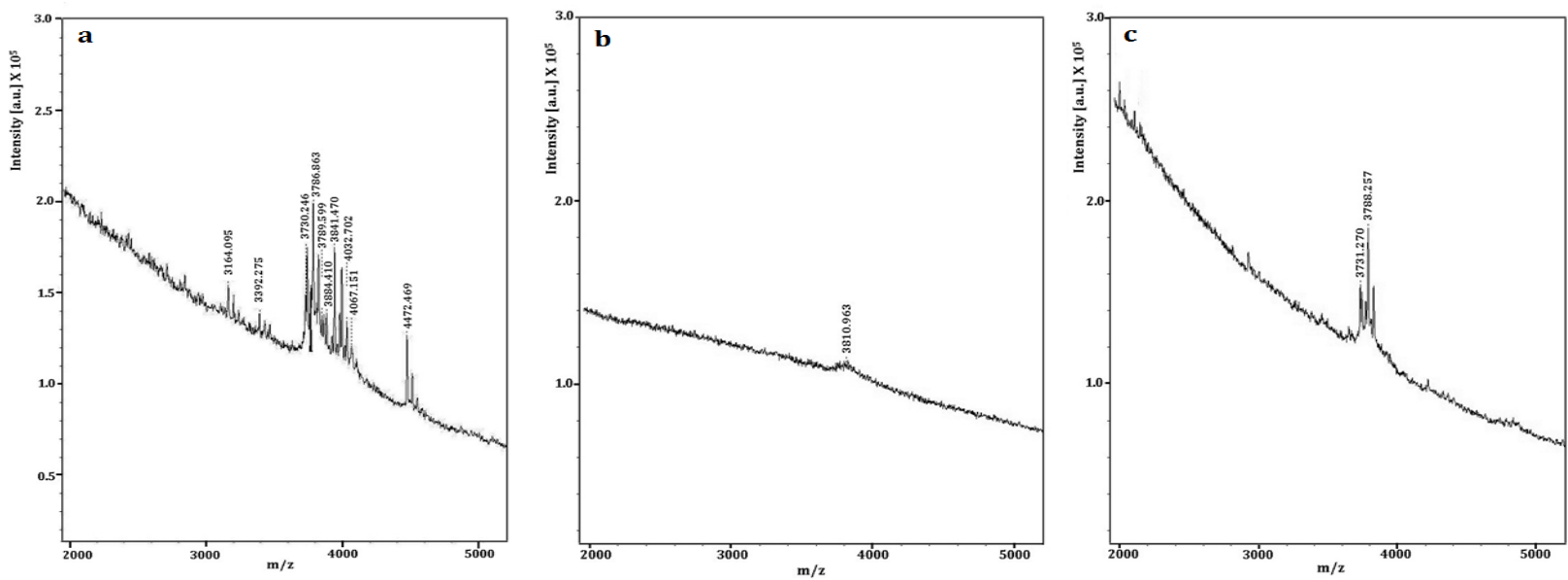

Figure 4 MALDI-TOF analysis of peptides isolated from 21 days old

a. control seedlings b. nonprimed seedlings and $\mathbf{c}$. haloprimed seedlings of Vigna mungo.

HPLC chromatograms of peptides isolated from control seedlings of $C$. cajan depicted maximal expression and abundance of peptides at $\mathrm{RT}=5.196$. In $150 \mathrm{mM} \mathrm{NaCl}$ treated seedlings, the abundance of the same peak was found to get reduced by $84 \%$ over peptides of control seedlings. This lowering of peptide abundance under $\mathrm{NaCl}$ stress probably resulted in the generation of other disintegrated peptide peaks till before RT=8.0. However, peptides isolated from haloprimed seedlings of $C$. cajan exhibited peak area which was $52 \%$ more than that of peak area of peptides isolated from $150 \mathrm{mM} \mathrm{NaCl}$ treated seedlings and also the deterioration in peptide content was reduced to about $78 \%$ over control peptides (Figure 3b).

\subsection{MALDI-TOF analysis}

By MALDI-TOF analysis, the spectrum obtained from peptides isolated from 21days old non-treated or control seedlings of $V$. mungo depicted that several LMW peptides were variably responsible for germination and seedling growth under non- stressed conditions. Noteworthy signals were recorded at $\mathrm{m} / \mathrm{z}$ values of $3164.095,3392.275,3730.246,3786.693,3849.599$, $3884.410, \quad 3941.740, \quad 4032.702, \quad 4067.151$ and 4472.469 representing molecular weight of peptides in Dalton (Da). The peptide having molecular weight of 3786.693Da obtained from control seedlings were prominently expressed (Figure 4a).

For peptides obtained from $150 \mathrm{mM} \mathrm{NaCl}$ treated seedlings, only one signal was found at $\mathrm{m} / \mathrm{z}$ value $3810.963 \mathrm{Da}$ which represented the molecular weight of the only peptide that could express itself and that too in very low concentration probably due to induced $\mathrm{NaCl}$ exposure. The molecular weight of this peptide is very close to the abundant peptide expressed in control seedlings (Figure 4b).

However, spectrum obtained for peptides isolated from haloprimed seedlings of $V$. mungo showed that the abundance of the peptide obtained at $\mathrm{m} / \mathrm{z} 3788.257$ (indicative of the molecular weight of the peptide in Dalton) was expressed in abundance 
conferring to better growth of the seedlings under $\mathrm{NaCl}$ stress. The molecular weight obtained for the peptide from haloprimed seedlings was also very close to the peptide obtained from control seedlings. Another signal was also obtained at $\mathrm{m} / \mathrm{z} 3731.270$ indicating presence of a peptide that was also present in control seedlings having molecular weight of $3730.246 \mathrm{Da}$ (Figure 4c).

Similarly, spectrum obtained for peptides isolated from nontreated seedlings of $C$. cajan exhibited a single $\mathrm{m} / \mathrm{z}$ signal revealing presence of peptide having molecular weight of 3702.078Da (Figure 5a). The abundance was also satisfactory indicating abundance of peptide during seedling germination and growth. The obtained results could be corroborated with the HPLC generated peaks of same peptide. In $\mathrm{NaCl}$ treated seedlings, the abundance of peptide was appreciably reduced as obtained from the $\mathrm{m} / \mathrm{z}$ signal spectrum indicating molecular weight of the peptide to be 3499.527Da (Figure 5b). Peptides isolated from haloprimed seedlings of $C$. cajan seedlings again indicated that peptide abundance obtained at $\mathrm{m} / \mathrm{z}$ signal of
3848.845Da probably responsible for better growth in haloprimed C. cajan seedlings (Figure 5c).

\subsection{CD analysis of peptide structures}

The LMW peptides isolated from $\mathrm{NaCl}$ challenged seedlings acquired lower percentages of secondary structure conformations (alpha helices + beta sheet/strand/turns) over peptides isolated from control seedlings (Table 1). The content of secondary structure decreased to about $51.6 \%$ in Vigna and by $24.1 \%$ in peptides isolated in Cajanus seedlings. However, peptides isolated from haloprimed test seedlings generated higher percentage of ordered secondary structure, $59.8 \%$ in Vigna and $44.5 \%$ in Cajanus indicative of stress release under salt stressed conditions. Disordered structure of peptides were found to be higher in salt stressed Cajanus by $57.4 \%$ seedlings and less in Vigna by $48.4 \%$. These percentages of disordered conformation decreased to $35.6 \%$ in peptides isolated from haloprimed seedlings of Cajanus and to $35.4 \%$ in Vigna.
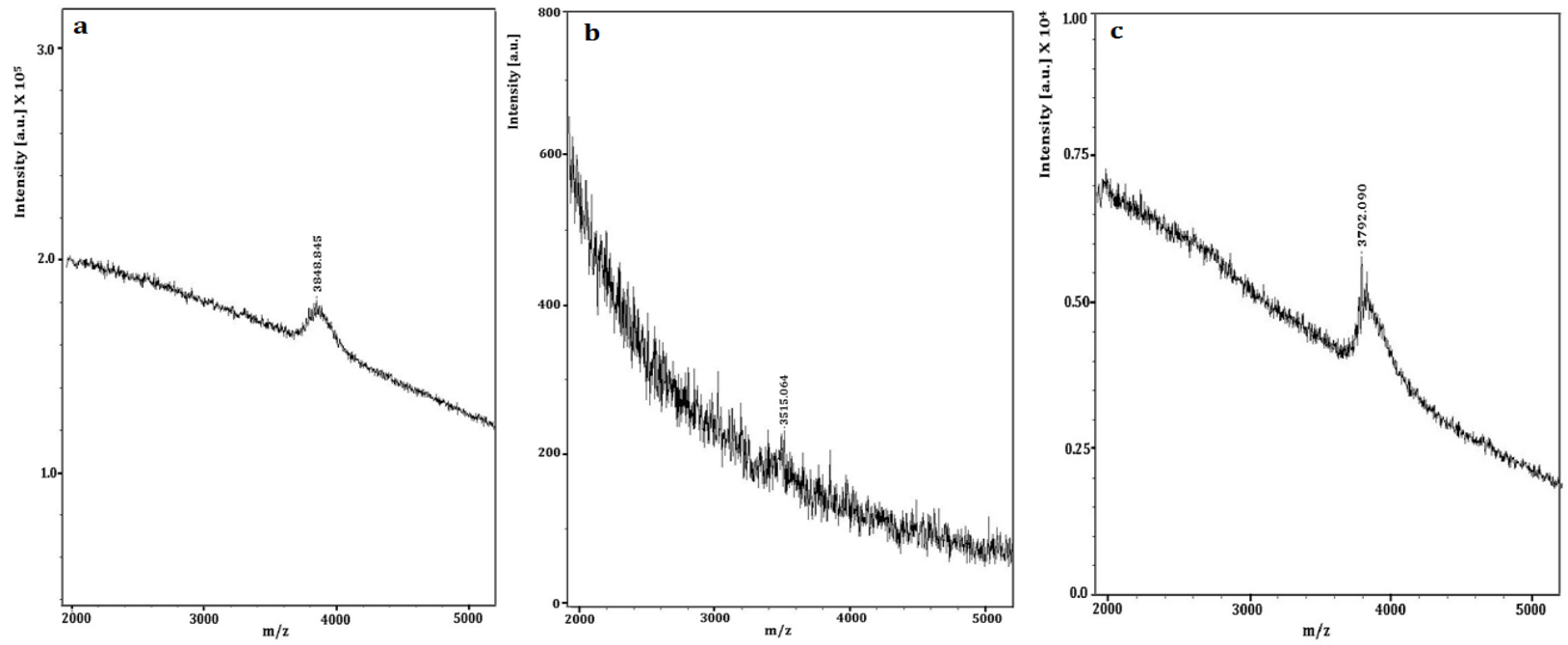

Figure 5 MALDI-TOF analysis of peptides isolated from 21 days old a. control seedlings b. nonprimed seedlings and c. haloprimed seedlings of Cajanus cajan.

Table 1 Estimates of Secondary structures in percentages from analysis of Circular Dichroism spectra.

\begin{tabular}{|c|c|c|c|c|c|c|}
\hline \multirow[b]{2}{*}{ Conformations } & \multicolumn{3}{|c|}{ Vigna mungo } & \multicolumn{3}{|c|}{ Cajanus cajan } \\
\hline & Control & $\begin{array}{c}150 \mathrm{mM} \\
\text { Nonprimed }\end{array}$ & $\begin{array}{c}150 \mathrm{mM} \\
\text { Haloprimed }\end{array}$ & Control & $\begin{array}{c}150 \mathrm{mM} \\
\text { Nonprimed }\end{array}$ & $\begin{array}{c}150 \mathrm{mM} \\
\text { Haloprimed }\end{array}$ \\
\hline$\alpha$-Helix (Regular + distorted) & 0.0 & 0.0 & 4.8 & 0.0 & 18.4 & 19.8 \\
\hline $\begin{array}{l}\text { Antiparallel } \beta \text {-sheet (Left twisted+ } \\
\text { Relaxed+ Right twisted) }\end{array}$ & 38.0 & 0.0 & 31.2 & 37.7 & 0.0 & 0.0 \\
\hline Parallel $\beta$-strand & 0.0 & 0.0 & 0.0 & 0.0 & 14.4 & 26.9 \\
\hline Turn & 62.0 & 51.6 & 28.6 & 12.8 & 9.7 & 17.6 \\
\hline Others & 0.0 & 48.4 & 35.4 & 49.4 & 57.4 & 35.6 \\
\hline
\end{tabular}

Journal of Experimental Biology and Agricultural Sciences http://www.jebas.org 


\subsection{Bioassay Results}

\subsubsection{Germination test}

Surface sterilized blackgram and pigeon pea seeds were incubated in peptides isolated from their respective seedlings and treatments for 7 days. Of a total of 45 plated seeds, 38 germinated in case of blackgram (Figure 6a) and for pigeon pea it was 32 (Figure 6d). Peptides isolated from nonprimed $\mathrm{NaCl}$ stressed seedlings exhibited inhibition in rate of their respective seed germination to about $63 \%$ in blackgram (Figure 6b) and by 66\% in pigeon pea (Figure 6e) in comparison to the effect of peptides that were isolated from their respective control seedlings. However on exposing seeds of both the cultivars to peptides isolated from their respective haloprimed seedlings depicted better seed germination rate, where the rate of inhibition was appreciably narrowed down to $32 \%$ in blackgram (Figure 6c) and 25\% in pigeon pea (Figure 6f) respectively over non-primed control.

\subsubsection{Stomatal bioassay}

Both the legume cultivars revealed that when epidermal peels were exposed to peptides isolated from control seedlings, stomata remained open (Figure 7a, 8a) but in peels exposed to peptides isolated from $\mathrm{NaCl}$ stressed seedlings, the guard cells were found to remain flaccid that caused stomatal closure (Figure $\mathbf{7 b}, \mathbf{8 b}$ ). However, when peels were subjected to peptides isolated from haloprimed seedlings, stomatal guard cells gained turgidity that resulted in stomatal opening (Figure 7c, $\mathbf{8 c}$ ).

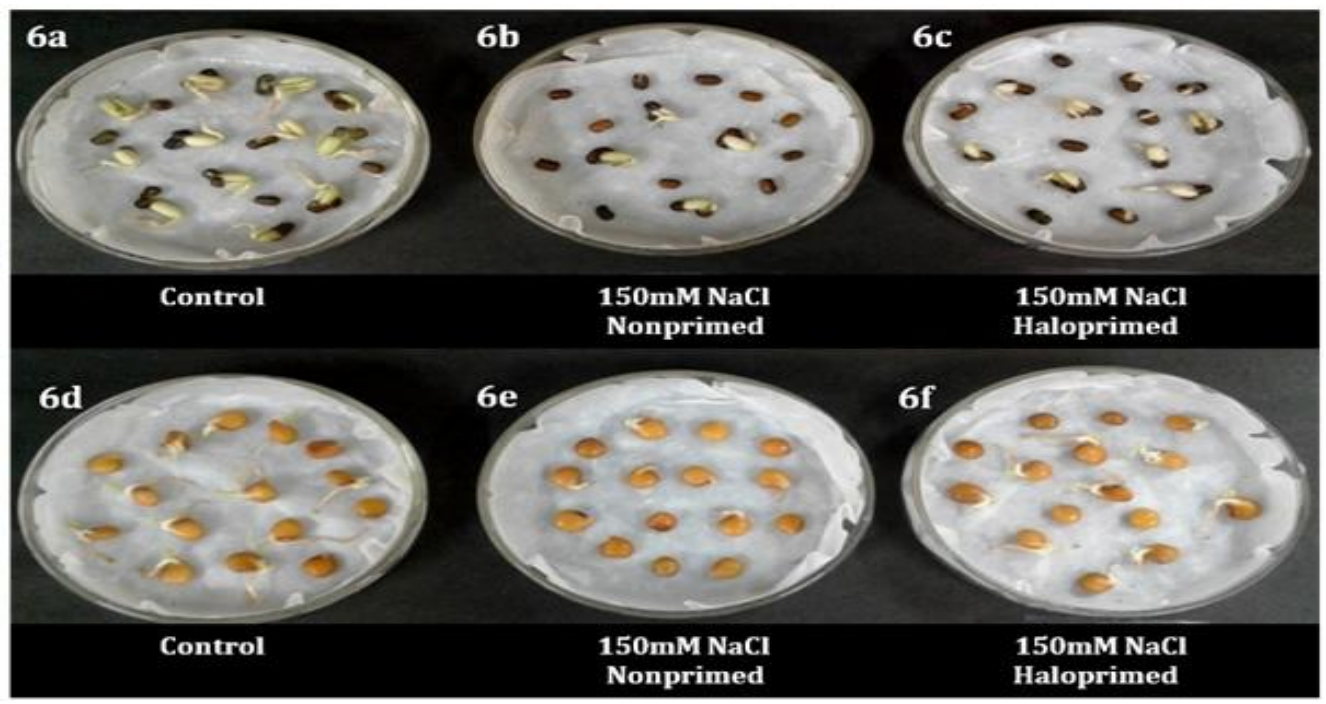

Figure 6: Effect of isolated LMW peptides (0.3-5.0kDa) on seed germination of nonprimed and haloprimed seeds of Vigna mungo. (a. control; b. $150 \mathrm{mM}$ nonprimed; c. $150 \mathrm{mM}$ haloprimed) and Cajanus cajan (d. control; e. $150 \mathrm{mM}$ nonprimed; f. 150mM haloprimed).
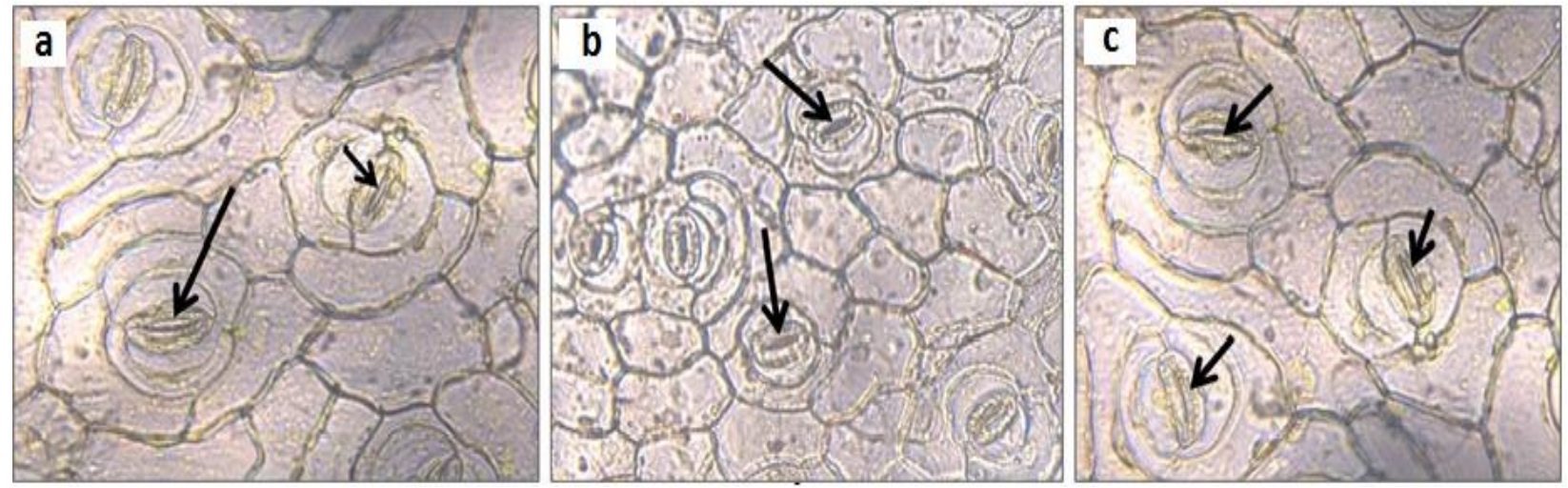

Figure 7 Effect of LMW peptides (0.3-5.0 kDa) on stomatal regulation in Vigna mungo a: Peptides isolated from control seedlings depicted opening of stomata $b$. Peptides isolated from salt stressed seedlings revealed complete stomatal closure c. Application of peptides isolated from haloprimed seedlings exhibited partial opening of stomata.

Journal of Experimental Biology and Agricultural Sciences http://www.jebas.org 

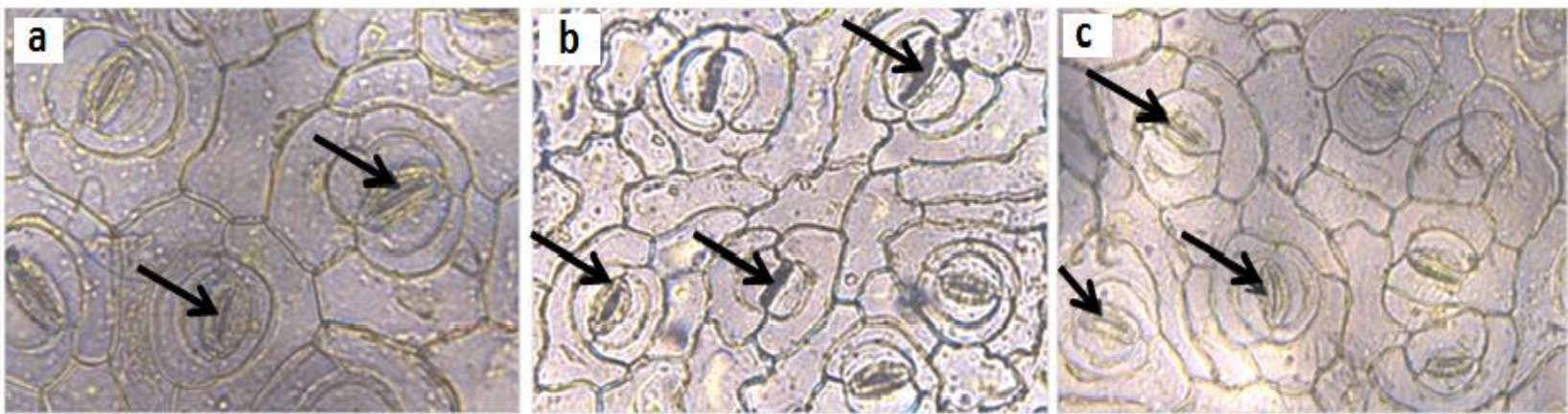

Figure 8 Effect of LMW (0.3-5kDa) on stomatal regulation in Cajanus cajan a: Peptides isolated from control seedlings depicted opening of stomata b. Peptides isolated from salt stressed seedlings revealed complete stomatal closure c. Application of peptides isolated from haloprimed seedlings exhibited partial opening of stomata.

\subsubsection{DPPH radical scavenging activity}

DPPH radical scavenging activity was performed to detect the free radical scavenging activities of the peptides isolated from blackgram and pigeon pea (Figure 9). Peptides isolated from control seedlings exhibited radical scavenging activity of about $48 \%$ in blackgram and $34 \%$ in pigeon pea. In blackgram, the radical scavenging activity of peptide was reduced to about $28 \%$ whereas in pigeon pea it decreased to $8 \%$, indicating higher radical scavenging in blackgram than pigeon pea over peptides isolated from their respective control seedlings. However, peptides isolated from haloprimed seedlings exhibited higher radical scavenging activity of about $43 \%$ in blackgram and $21 \%$ in pigeon pea over its control peptides.

\subsubsection{Nitric oxide scavenging activity}

It has been demonstrated that under $\mathrm{NaCl}$ stress, nitric oxide scavenging activity of peptides obtained from both the cultivars decreased, the inhibition being more in Vigna than Cajanus (Figure 10). In Vigna, peptides isolated from the control seedlings exhibited 25\% inhibition in their nitric oxide scavenging activity which was reduced to about $22 \%$ in peptides obtained from $\mathrm{NaCl}$ stressed seedlings indicating less quenching of radicals. Haloprimed seedlings of Vigna mungo produced peptides that showed higher inhibition of about $26 \%$ over the peptides isolated from control plants indicating improved nitric oxide scavenging activity. The peptides obtained from seedlings of Cajanus raised in water exhibited $24 \%$ inhibition in nitric oxide scavenging activity. The said inhibition was decreased to $20 \%$ in salt stressed Cajanus seedlings indicating lesser scavenging of nitric oxide

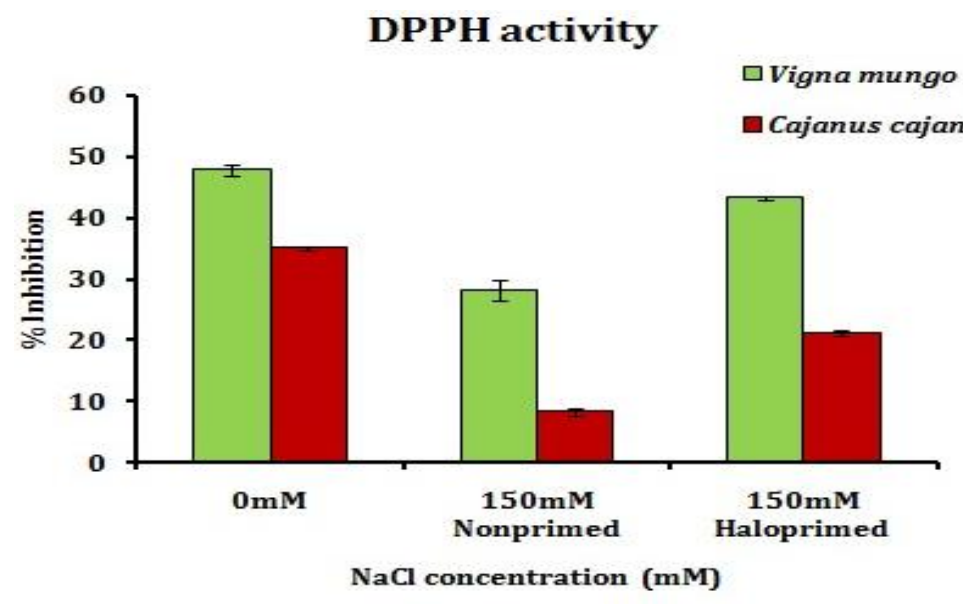

Figure 9 DPPH activity of LMW peptides isolated from 21days old control, nonprimed and haloprimed seedlings of Vigna mungo and Cajanus cajan. Values are mean \pm SE with three replicates. * indicates statistically significant at $\mathrm{p} \leq 0.05$ compared to nonprimed control.

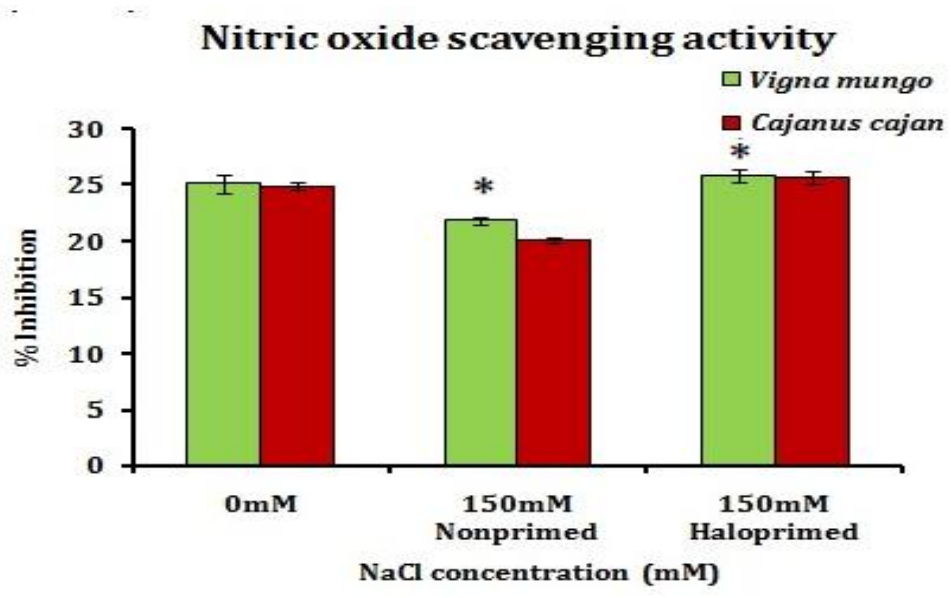

Figure 10: NO scavenging activity of LMW peptides isolated from 21days old control, nonprimed and haloprimed seedlings of Vigna mungo and Cajanus cajan. Values are mean \pm SE with three replicates. * indicates statistically significant at $\mathrm{p} \leq 0.05$ compared to nonprimed control. 
over the activity of its non-primed control peptides. However, peptides from haloprimed seedlings showed $25 \%$ inhibition over control peptides indicating greater radical scavenging property of haloprimed peptides.

\section{Discussion}

After 3 weeks of growth, $\mathrm{NaCl}$ induced toxicity resulted in stunted growth of V. mungo and C. cajan seedlings. This indicated salt induced metabolic perturbation was responsible for retarded growth of seedlings. However, when seeds of both the legume cultivars were primed with mild or sublethal dose of $\mathrm{NaCl}$ $(50 \mathrm{mM})$, increase in root and shoot lengths were recorded, probably an indication of their stress release due to halopriming. Similar report has been published in salt stressed $V$. radiata (Saha et al., 2010), N. sativa (Gholami et al., 2015) and Lolium perene (Tilaki \& Behtari, 2017).

Under $\mathrm{NaCl}$ stress, $\mathrm{Na}^{+}$and $\mathrm{Cl}^{-}$contents increased in the seedlings of salt stressed $V$. mungo and $C$. cajan. Accumulation of $\mathrm{Na}^{+}$and $\mathrm{Cl}^{-}$ions were more in C. cajan than $V$. mungo. Uptake of $\mathrm{Na}^{+}$ions facilitated $\mathrm{Cl}^{-}$ions to enter the roots down the chemical gradient (Moussa, 2004). Similar results were reported in salt-stressed $V$. radiata and Broussonetia papyrifera (Saha et al., 2012; Zhang et al., 2013). Under optimum physiological conditions, $\mathrm{K}^{+}$ions are known to contribute to $6-10 \%$ of the plant dry weight (Raven et al., 1976; Shin, 2014) and serves as a major inorganic osmolyte (Shabala \& Cuin, 2008). It plays essential role in regulating several physio-biochemical processes of which stomatal opening and closing is crucial for maintenance of undisturbed synthesis of photoassimilates within plants (Shabala, 2003; Hasanuzzaman et al., 2018). $\mathrm{NaCl}$ exposure in the test seedlings resulted in reduced $\mathrm{K}^{+}$contents and increased $\mathrm{Na}^{+}$contents thereby causing stomatal regulation to get hampered significantly in both the legume cultivars as $\mathrm{Na}^{+}$ions failed to replace the beneficial aspect of $\mathrm{K}^{+}$ ions. This happened because sodium ions competed with $\mathrm{Na}^{+}-\mathrm{K}^{+}$ co-transporter under salinity (Zhu, 2003; Almeida et al., 2017).

Halopriming of seeds of $V$. mungo and C. cajan with $50 \mathrm{mM} \mathrm{NaCl}$ resulted in decreased uptake of $\mathrm{Na}^{+}$and $\mathrm{Cl}^{-}$ions and increased accumulation of $\mathrm{K}^{+}$ions in both the cultivars under $150 \mathrm{mM} \mathrm{NaCl}$ exposure compared to non-primed control. Present outcomes are in agreement with the results obtained by seed preconditioning in salt stressed mungbean (Saha et al., 2012). This occurred due to preferential uptake of $\mathrm{K}^{+}$ions over $\mathrm{Na}^{+}$ions into the xylem element (Carden et al., 2003). Moreover, halopriming of seeds stimulated $\mathrm{Na}^{+} / \mathrm{H}^{+}$antiporter exchange activity of SOS1 protein pump as in Hordeum vulgare which promoted exclusion of $\mathrm{Na}^{+}$ from the root cells of haloprimed seedlings.

Small peptides play beneficial roles in dictating intercellular and intracellular signalling cascades related to growth and metabolism in plants (Matsubayashi \& Sakagami, 2006). Therefore, current research was aimed at isolation of ultra-filtered LMW peptides from both the legume cultivars which were subjected to HPLC and MALDI-TOF analysis. This aided not only in determining the peptide occurrences but also to compare their variations in content during their normal seedling germination and under salt stressed conditions. Further role of halopriming in alleviating the salt induced adversities could also be deciphered. HPLC chromatograms of peptides isolated from both the test seedlings portrayed that in non-primed control seedlings, maximum peptide expression and occurrence took place during normal seedling growth. However, peptides obtained from $\mathrm{NaCl}$ stressed seedlings generated chromatogram that showed lesser peptide abundance compared to non-primed control seedlings. This probably indicated that several LMW peptides which usually participate in growth processes of plants were degraded under salinity. Halopriming of seeds helped to overcome such adversities to considerable extent in salt stressed conditions as indicated by increased peak area and reappearance of a few peaks that was noted in control seedlings. This reveal that ameliorative efficacy of halopriming lead to better growth and development of both the pulses under $\mathrm{NaCl}$ stressed environments. Matrix-assisted laser desorption ionization (MALDI) being a soft source of molecule(s) ionisation was utilized to generate fragmentation of isolated peptide(s) thereby helping to determine their molecular weight (Castañeda-Ovando et al., 2012). For both the tested materials, molecular weight of the most prominent peptide obtained from the $\mathrm{m} / \mathrm{z}$ signals of MALDI spectrum was found to be close to each other. Intensities of this prominent peak showed a trend that was similar to its occurrence in HPLC spectra for both cultivars. The appearance of signal having m/z 3731.270 in MALDI spectra of peptides from haloprimed blackgram seedlings was similar to that of peptide signal at $\mathrm{m} / \mathrm{z} 3720.246$ derived from its control seedlings. This indicated that halopriming resulted in reappearance of that LMW peptide facilitating better germination and growth of haloprimed seeds than directly salt treated seeds. Although no such peptide reappearances were noted in MALDI spectrum of $C$. cajan but, role of halopriming was evident from the increased peak intensity of haloprimed peptides over direct salt treated ones. Thus, seed halopriming in both the cultivars imparted better growth of primed seeds under salt stressed conditions due to prior salt acclimation.

Circular dichroism spectroscopy helped to determine percentages of secondary structure adopted by the peptides of both the pulses under salt stress and how these conformations altered in case of haloprimed peptides under salt exposure. Secondary conformations were found to decrease under $\mathrm{NaCl}$ induced desiccation manifesting deformation and distortion in peptide structure usually involved in normal plant growth and developmental processes. This reflected salt induced denaturation 
of peptides, formation of more flexible, unfolded, unordered structures which affected the equilibrium between the contents of $\alpha$ helical and $\beta$-sheet structures. Moreover, unordered structures increased in peptides obtained from salt stressed seedlings probably due to protein aggregation as it was observed in whey protein isolates under temperature and $\mathrm{pH}$ variations (Topmczynska-Mleko et al., 2014). But, in haloprimed peptides the percentages of secondary conformations of peptides were much more regularized over peptides of salt stressed seedlings. Higher percentages of secondary conformations and lower percentages of disorder probably helped the primed seeds to impart efficient metabolism under salinity stress in both the pulses.

The above obtained results were validated by bioassays performed with the isolated LMW peptides from both the cultivars. Bioassays helped to demonstrate the putative effects of respective peptides on seed germination and stomatal regulation and thereby seedling growth from which the authors could get some notion regarding their role on growth regulation in the test seedlings. Abundance of LMW peptide from control seedlings of both the varieties, promoted seed germination rate and kept stomatal pore open for $\mathrm{CO}_{2}$ assimilation. This could be correlated with the higher $\mathrm{K}^{+}$ion accumulation in shoots and satisfactory antioxidative activities of LMW peptides favouring luxuriant growth of both cultivars. Similar antioxidative properties have been reported in LMW isolated from mulberry plants (Jha et al., 2014). But, the peptides isolated from $\mathrm{NaCl}$ challenged seedlings of both varieties narrowed down the germination rate, failed to arouse turgidity in guard cells due to decreased uptake of $\mathrm{K}^{+}$ions in shoot thereby resulting in stomatal shut down and hindered $\mathrm{CO}_{2}$ fixation. Decrease in free radical scavenging activities of these peptides derived from $\mathrm{NaCl}$ stressed seedlings is also in agreement with the above physiochemical events causing stunted seedling growth in both the varieties. Similar effect has been reported in Schizonepeta tenuifolia when exposed to high salt doses at and above $75 \mathrm{mM} \mathrm{NaCl}$ (Zhou et al., 2018). But, peptides obtained from haloprimed seedlings exhibited improved seed germination, increased turgidity of stomatal guard cells causing stomatal opening and carbon assimilation under $\mathrm{NaCl}$ stress. This could be corroborated with increased accumulation of $\mathrm{K}^{+}$ions in shoots of haloprimed cultivars and antioxidative activity of LMW peptides that resulted in improved growth in both the varieties on salt exposure. However, the scavenging activity of peptides was found to be more efficient in $V$. mungo than $C$. cajan. This indicated more stress tolerance capability of blackgram over pigeon pea under $\mathrm{NaCl}$ stress, when seeds were haloprimed.

Therefore, adoption of cost effective halopriming technique by poor farmers may help to boost legume production by improving crop stand in saline prone agricultural lands to partially meet up with the food crisis of the flourishing world population.

\section{Conclusion}

To conclude authors relate that under $\mathrm{NaCl}$ stress, growth was inhibited in both blackgram and pigeonpea seedlings due to lower abundance of LMW peptides. The isolated peptides exhibited antioxidant properties that effectively scavenged reactive oxygen species when present in plenty. The peptides were stressresponsive and increased on seed halopriming when compared to that of salt stressed sets. Peptides isolated from haloprimed $V$. mungo had better antioxidant properties than those isolated from haloprimed $C$. cajan which could be correlated with improved growth in $V$. mungo as recorded by the authors. Secondary structural conformations were highly hampered under salt stress. But haloprimed $V$. mungo and $C$. cajan seeds showed improved physiological performances indicating that adopting this cost effective halopriming technique helped to overcome salt induced adversities under salt exposure. Moreover, this technique may help to increase legume production in saline prone agricultural lands to meet up with the food demands of increasing population.

\section{Acknowledgements}

The authors acknowledge Centre for Advanced Study, Department of Botany, University of Calcutta for instrument facilities. The authors are thankful to the Central Instrument Facility, Bose Institute, Kolkata for HPLC analysis and Central Instrument Facility, The Indian Association for Cultivation of Science, Kolkata for MALDI-TOF analysis.

\section{Conflicts of Interest and financial disclosure}

The authors declare that no conflict of interest exists. This work was supported by a Research Grant No. 1012(Sanc.)/ST/P/ S\&T/2G-2/2013 obtained from the Department of Science and Technology, Government of West Bengal.

\section{References}

Albert M (2013) Peptides as trigger of plant defence. Journal of Experimental Biology 64: 5269-5279.

Almeida DM, Oliveira MM, Saibo NJM (2017) Regulation of $\mathrm{Na}^{+}$ and $\mathrm{K}^{+}$homeostasis in plants: towards improved salt tolerance in crop plants. Genetics and Molecular Biology 40: 326-345.

Azzoni AR, Takahashi K, Woodard SL, Miranda EA, Nikolov ZL (2005) Purification of recombinant appotinin produced in transgenic corn seed: separation from CTI utilizing Ionexchange chromatography. Brazilian Journal of Chemical Engineering 22: 323-330.

Bircheneder S, Dresselhaus T (2016) Why cellular communication during plant reproduction is particularly mediated by CRP signalling. Journal of Experimental Botany 67: 4849-4861. 
Biswas S, Biswas AK, De B (2018) Metabolomics analysis of Cajanus cajan L. seedlings unravelled amelioration of stress induced responses to salinity after halopriming of seeds. Plant Signaling and Behavior 13: e1489670.

Carden DE, Walker DJ, Flowers TJ, Miller AJ (2003) Single-cell measurements of the contributions of cytosolic $\mathrm{Na}^{+}$and $\mathrm{K}^{+}$to salt tolerance. Plant Physiology 131: 676-683.

Castañeda-Ovando A, Sedo O, Havel J, Pacheco L, Galán-Vidal CA, Lopez EC (2012) Identification of anthocyanins in red grape, plum and capulin by MALDI-ToF MS. Journal of the Mexican Chemical Society 56: 378-383.

Chatterjee P, Biswas S, Biswas AK (2018) Sodium chloride primed seeds modulate glutathione metabolism in legume cultivars under $\mathrm{NaCl}$ stress. American Journal of Plant Physiology 13: 8-22.

Chrysargyris A, Panayiotou C, Tzortzakis N (2016) Nitrogen and phosphorus levels affected plant growth, essential oil composition and antioxidant status of lavender plant (Lavandula angustifolia Mill.). Industrial Crops and Products 83: 577-586.

Czyzewicz N, Yue K, Beeckman T, De Smet I (2013) Message in a bottle: small signalling peptide outputs during growth and development. Journal of Experimental Botany 64: 5281-5296.

Etesami H, Beattie GA (2018) Mining halophytes for plant growthpromoting halotolerant bacteria to enhance the salinity tolerance of non-halophytic crops. Frontiers in Microbiology 9: 1-20.

Gholami M, Mokhtarian F, Baninasab B (2015) Seed halopriming improves the germination performance of black seed (Nigella sativa L.) under salinity stress conditions. Journal of Crop Science and Biotechnology 18: 21-26.

Ghosh A, Mandal P, Sircar PK (2010) Wheat (Triticum aestivum) peptide(s) mimic gibberellin action and regulate stomatal opening. Indian Journal of Experimental Biology 48: 77-82.

Hara K, Kajita R, Torii KU, Bergmann DC, Kakimoto T (2007) The secretory peptide gene EPF1 enforces the stomatal one-cellspacing rule. Genes and Development 21: 1720-1725.

Hasanuzzaman M, Bhuyan MHM, Nahar K, Hossain MS, Mahmud JA, Hossen MS, Masud AAC, Moumita OC, Fujita M (2018) Potassium: A vital regulator of plant responses and tolerance to abiotic stresses. Agronomy 8: 31-59.

Hussain K, Majeed A, Nawaz K, Bhatti KH, Nisar FK (2009) Effect of different levels of salinity on growth and ion contents of black seeds (Nigella sativa L.). Current Research Journal of Biological Sciences 1: 135-138.
Jha S, Ghosal M, Gupta SK, Ghosh A, Mandal P (2016) In-vitro free radical scavenging potential of oligopeptides derived from wheat and mungbean. International Journal of Pharmacy and Pharmaceutical Sciences 8: 428-432.

Jha S, Mandal P, Bhattacharya P, Ghosh A (2014) Free-radical scavenging properties of low molecular weight peptide(s) isolated from S1 cultivar of mulberry leaves and their impact on Bombyx mori (L.) (Bombycidae). Journal of Animal Science and Biotechnology 5: 16-24.

Leung SO, Yeung HW, Leung KN (1987) The immunosuppressive activities of two abortifacient proteins isolated from seeds of bittermelon (Momordica charantia). Immunopharmacology 13: 159-171.

Lindsey K, Casson S, Chilley P (2002) Peptides: new signalling molecules in plants. Trends in Plant Science 7: 78-83.

Mandal P, Misra TK, Sarkar A, Ghosh A, Sircar PK (2008) Dynamic peptide profiles of germinating mungbean: In relation to their nature and separation pattern. Indian Journal of Plant Physiology 13: 111-117.

Marcocci L, Packer L, Droy-Lefaix MT, Sekaki A, Gardes-Albert M (1994) Antioxidant action of Ginkgo biloba extracts EGb 761. Methods in Enzymology 234: 462-475.

Maróti G, Downie JA, Kondorosi É (2015) Plant cysteine-rich peptides that inhibit pathogen growth and control rhizobial differentiation in legume nodules. Current Opinion in Plant Biology 26: 57-63.

Matsubayashi Y (2014) Posttranslationally modified small-peptide signals in plants. Annual Review of Plant Biology 65: 385-413.

Matsubayashi Y, Sakagami Y (2006) Peptide hormones in plants. Annual Review of Plant Biology 57: 649-674.

Moussa HR (2004) Amelioration of salinity-induced metabolic changes in soyabean by weed exudates. International Journal of Agriculture and Biology 6: 499-503.

Muñoz-García J, Ares S (2016) Formation and maintenance of nitrogen-fixing cell patterns in filamentous cyanobacteria. Proceedings of the National Academy of Sciences of the United States of America 113: 6218-6223.

Murphy E, Smith S, De Smet I (2012) Small signalling peptides in Arabidopsis development: How cells communicate over short distance. Plant Cell 24: 3198-3217.

Mylona P, Pawlowski K, Bisseling T (1995) Symbiotic nitrogen fixation. Plant Cell 7: 869-885. 
Oh E, Seo PJ, Kim J (2018) Signaling peptides and receptors coordinating plant root development. Trends in Plant Science 23: 337-351.

Parida AK, Das AB (2005) Salt tolerance and salinity effects on plants: a review. Ecotoxicology and Environmental Safety 60: 324-349.

Raven PH, Evert RF, Curtis H (1976) Biology of plants. Worth Publishers, New York.

Saha P, Chatterjee P, Biswas AK (2010) $\mathrm{NaCl}$ pretreatment alleviates salt stress by enhancement of antioxidant defense and osmolyte accumulation in mungbean (Vigna radiata L. Wilczek). Indian Journal of Experimental Biology 48: 593-600.

Saha P, Kunda P, Biswas AK (2012) Influence of sodium chloride on regulation of Krebs cycle intermediates and enzymes of respiratory chain in mungbean. Plant Physiology and Biochemistry 60: 214-222.

Senthilkumar S, Chang E, Jayakumar R (2008) Diffusible amyloid oligomers trigger systemic amyloidosis in mice. Biochemistry Journal 415: 207-215.

Shabala S (2003) Regulation of potassium transport in leaves: from molecular to tissue level. Annals of Botany 92: 627-634.

Shabala S, Cuin TA (2008) Potassium transport and plant salt tolerance. Physiologia Plantarum 133: 651-669.

Sheen RT, Kahler HL (1938) Effect of ions on mohr method for chloride determination. Industrial and Engineering Chemistry Analytical Edition 10: 628-629.

Shin R (2014) Strategies for improving potassium use efficiency in plants. Molecular Cell 37: 575-584.

Sugano SS, Shimada T, Imai Y, Okawa K, Tamai A, Mori M, Hara-Nishimura I (2010) Stomagen positively regulates stomatal density in Arabidopsis. Nature 463: 241-244.
Tilaki GAD, Behtari B (2017) Alleviation of ionic and osmotic stress of salinity in seedling emergence of Lolium perenne L. with halopriming treatments growing in an hydroponic system. Journal of Plant Nutrition 40: 219-226.

Topmczynska-Mleko M, Kamysz E, Sikorska E, Puchalski C, Mleko S, Ozimek L, Kowaluk G, Gustaw W, WesolowskaTrojanowska M (2014) Changes of secondary structure and surface tension of whey protein isolate dispersions upon $\mathrm{pH}$ and temperature. Czech Journal of Food Sciences 32: 82-89.

Widodo PJH, Newbigin E, Tester M, Bacic A, Roessner U (2009) Metabolic responses of salt stress in barley (Hordeum vulgare L.) cultivars, Sahara and Clipper, which differ in salinity tolerance. Journal of Experimental Botany 60: 4089-4103.

Zehadi MJA, Masamba K, Li Y, Chen M, Chen X, Sharif HR, Zhong F (2015) Identification and purification of antioxidant peptides from Lentils (Lens culinaris) hydrolysates. Journal of Plant Sciences 3: 123-132.

Zhang M, Fang Y, Ji Y, Jiang Z, Wang L (2013) Effects of salt stress on ion content, antioxidant enzymes and protein profiles in different tissues of Broussonetia papyrifera. South African Journal of Botany 85: 1-9.

Zhang Y, Lewis K (1997) Fabatins: new antimicrobial plant peptides. FEMS Microbiology Letters 149: 59-64.

Zhou Y, Tang N, Huang L, Zhao Y, Tang X, Wang K (2018) Effect of salt stress on plant growth, antioxidant capacity, glandular trichome density, and volatile exudates of Schizonepeta tenuifolia Briq. International Journal of Molecular Sciences 19: 252-266.

Zhu JK (2003) Regulation of ion homeostasis under salt stress. Current Opinion in Plant Biology 6: 676-683. 